\title{
プラズマ加熱用中性粒子入射装置のクライオポンプ* 一原研での研究開発—
}

\author{
柴田 猛順** 松田慎三郎 ${ }^{* *}$ \\ (昭和55年11月 7 日 受理)
}

\begin{abstract}
Cryopump of Neutral Beam Injector for Plasma Heating Experiment
- Research and Development at JAERI-
\end{abstract}

Takemasa SHIBATA and Shinzaburo MATSUDA

(Japan Atomic Energy Research Institute, Tokai-mura, Naka, Ibaraki)

(Received November 7, 1980)

\section{1.はじめに}

中性粒子入射加熱によるプラズマ加熱は実験的にその 有効性が確かめられており ${ }^{11}$, 日本原子力研究所で 現在 建設中で昭和59年末完成予定の臨界プラズマ試験装置 (JT-60)でも，75 keV，20 MW の高速水素 原子ビーム による, プラズマの加熱が予定されている22. 中性粒子 入射装置の概要を図 1 に示す.

イオン源から引きだされた水素イオンは中性化セル中 で荷電交換して高速水素原子になり，プラズマ閉じ込め 用磁場を横切ってプラズマ中に入り，ここで再びイオン 化してプラズマを加熱する. 中性化されなかったイオン は偏向磁石で曲げられてビームダンプにあたり水素ガス になる．この水素ガスと中性化セルより流れだす水素ガ スの量は10〜100 Torr $l / / \mathrm{s}$ にもなる.これを効率よく排 気して $10^{-5}$ Torr 以下にしないと, 高速水素原子が偏向 磁石を通過後, 残留ガスと衝突して再イオン化したり, 室温の水素ガスがプラズマ中に流れこんでプラズマを冷 却することになる.このためビームラインを約 $10^{6} l / \mathrm{s} の$ 排気速度で排気しなければならない。

プラズマへのビーム入射の持続時間が $100 \mathrm{~ms}$ 以下の ときは，ビーム入射前に，中性粒子入射装置の大きな真 空容器をよく排気しておき，ビーム入射時の水素ガスを 大きな真空容器内に拡散させる方法を採用できる ${ }^{3)}$. し かしながら, 装置が大型化するに従い, ビーム入射の持

$*$ 昭和 55 年 9 月 5 日 日本真空協会 9 月研究例会で講演

** 日本原子力研究所核融合研究部 (茨城県那珂郡東海村白根)
続時間も100 msを越えるようになると, 水素ガスを真空 容器に拡散させただけでは中性粒子入射装置内の圧力は $10^{-4}$ Torr 以上になってしまう。このためビーム入射時 間が100〜300 ms となるアメリカのPLT, ISX-B, Doublet III などの中型トカマク装置の中性粒子入射装置は, クライオポンプを使用するようになった ${ }^{4 \sim 6)}$. 日本でも， $100 \mathrm{~ms} \sim 300 \mathrm{~ms}$ のビーム入射を行ら京大ヘリオトロン用 中性粒子入射装置は, クライオポンプにより水素排気を 行ら予定である7?. 臨界プラズマ達成をめざすアメリカ の $\mathrm{TFTR}^{8,9}$, ヨーロッパ連合の $\mathrm{JET}^{10)}$, ソ連の T-10$\mathrm{M}^{11)}$ ，の大型トカマク装置の中性粒子入射装置は, ビー ム入射時間が $0.5 \sim 10 \mathrm{~s}$ と長いため, すべての装置がクラ イオポンプを使用する予定である. 原研が建設中の JT60 中性粒子入射装置も, ビーム入射時間が $5 \sim 10 \mathrm{~s}$ と長 いためクライオポンプを用いる. 原研が，昭和50年に液 体へリウム冷却による凝縮型クライオポンプをJT-60 中 性粒子入射装置の主排気ポンプと決定したのは, 大きい 排気速度をもち，しかも数年以内に確実に実現可能なも のと考えたからであった．諸外国の大型装置について も，クライオポンプの採用を決定したのは原研と同時期 であった.

原研では，このポンプの開発のため昭和50年度より小 型クライオポンプ（排気速度 $12,000 l / \mathrm{s}^{12}$ および 60,000 $\left.l / \mathrm{s}^{133}\right)$ を製作し，その排気特性を調べてきた。 中性粒子 入射装置のクライオポンプは, 大電流の粒子ビームが存 在するところで作動する点が他のクライオポンプと異な るため，ポンプへのビーム入射実験 ${ }^{14,15)}$ も行った. JT- 


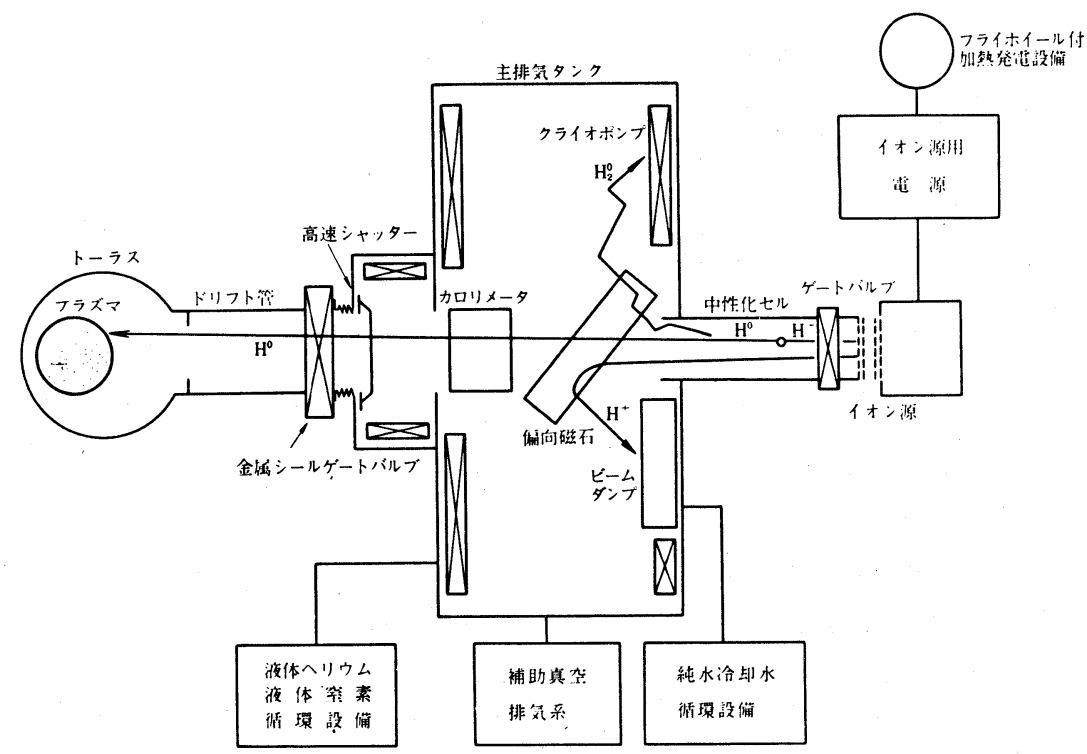

図 1 中性粒子入射装置 1 ユニットの構成

60では14個の入射孔に対応して14ユニットのビームライ ンで中性粒子入射システムが構成されるが，14ユニット の製作に先立ってその性能を確認するため，1 ユニット (JT-60用中性粒子入射装置原型ユニット) の建設を始 めて㧍り，昭和56年にその確証テストを行う予定であ る.この結果を反映させて, 昭和 56 年度後半より $\mathrm{JT}-60$ 中性粒子入射装置の建設に着手する.

ここでは, 排気速度 $60,000 \mathrm{l} / \mathrm{s}$ の小型クライオポンプ の排気特性 ${ }^{132}$ と, ビーム入射実験の結果 ${ }^{14,15)}$, および建 設の始まった原型ユニットのクライオポンプと液体ヘリ ウム, 液体窒素の循環システム (冷媒循環系) について 述べる.

2. 水素排気用 $60,000 l / s$ クライオポンプの 排気特性とビーム入射実験

このクライオポンプの鳥かん図を図 2 に, 排気速度測 定系の概略図を図 3 に示す.

クライオポンプは二組からなり，それぞれが液体へリ

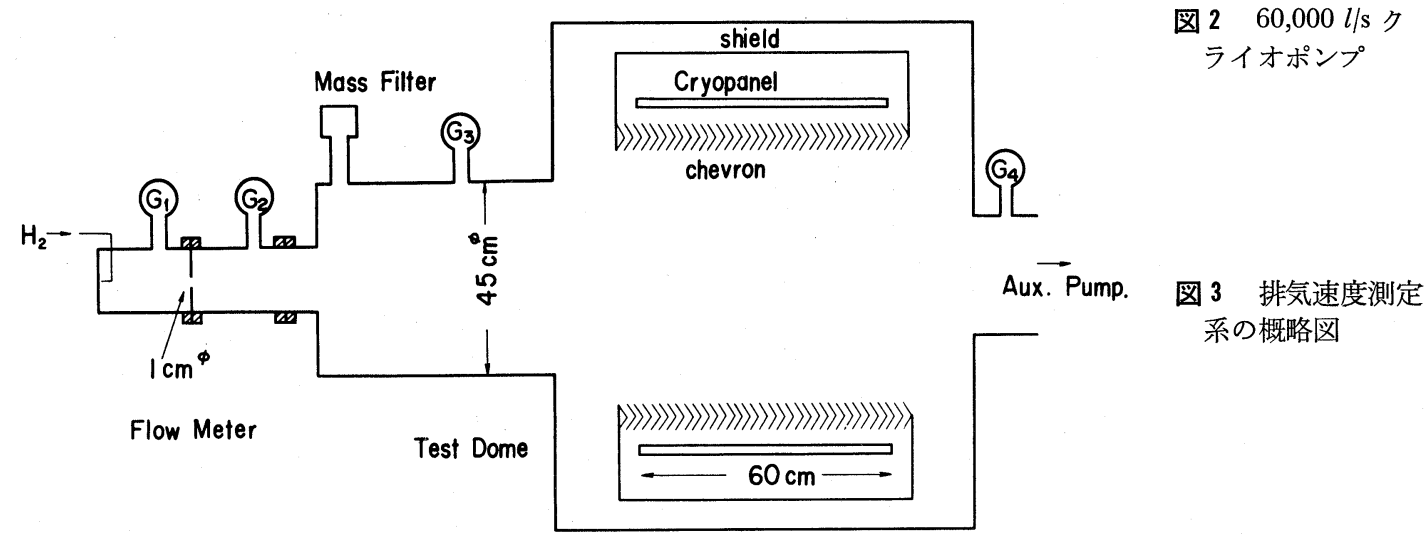




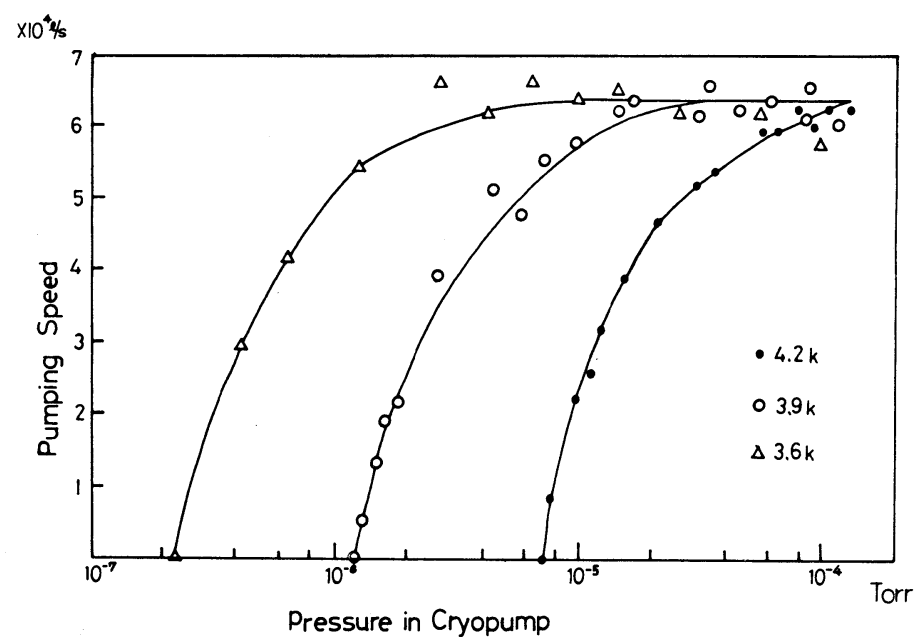

図 4 排気速度測定結果

図 5 水素ビーム入射実 験構成図

ウム槽, 液体窒素槽, シェブロン, $60 \mathrm{~cm} \times 60 \mathrm{~cm}$ のクラ イオパネルで作られている. シェブロンは銅板で，表面 が陽極酸化により黒色化されている.クライオパネル に，ステンレス板を二枚重㸚わせて等間隔に溶接して キルティング状にしたものである。一組のポンプの設計 排気速度は $30,000 \mathrm{l} / \mathrm{s}$ で, 二組で $60,000 \mathrm{l} / \mathrm{s}$ である.ク ライオパネルの温度は, 液体へリウム槽で発生する蒸気 をロータリーポンプで排気して，4.2K以下にすること もできる．排気速度 $S$ は水素ガスを流し，膨張法で校正 した電離真空計 $\mathrm{G}_{1}, \mathrm{G}_{2}, \mathrm{G}_{3}, \mathrm{G}_{4}$ により測定した圧力 $\mathrm{P}_{1}$, $\mathrm{P}_{2}, \mathrm{P}_{4}$ を用い，次の式から求めた。

$$
\begin{aligned}
& Q=C\left(P_{1}-P_{2}\right) \\
& S=Q / P_{4}
\end{aligned}
$$

ここでQ $は$ 水素の流量, $C$ は $1 \mathrm{~cm} \phi$ の穴のコンダクタン ス $(32 \mathrm{l} / \mathrm{s})$ である。ここで求めた流量はサーマルフロー メーターの指示ともよく一致した. 結果を図 4 亿示す. 水素の平衡蒸気圧が無視できる圧力領域で，排気速度は $63,000 \mathrm{l} / \mathrm{s}$ で設計排気速度とよく一致した.クライオパ ネルの各温度での平衡圧力も文献値 ${ }^{16)}$ とよく一致した。 JT-60 中性粒子入射装置では, クライオパネル単位面積 当りの水素凝縮量が1. 6 Torr $l / \mathrm{cm}^{2}$ となったときに, パ
ネルの再生を行う予定なので，クライオポンプの動作中 排気速度が減少しないことを確かめるために，再生予定 量の10倍以上までパネルに水素を凝縮させて，排気速度 の変化をみた. 結果は，パネルに水素を凝縮させても排 気速度は減少せず，むしろほとんど水素を凝縮していな いときの排気速度より，水素をある程度凝縮していると きの排気速度の方が大きいことがわかった。

大電流の高エネルギー粒子がポンプ内を通過する時の ポンプの排気性能の変化をみるため, ポンプの収納され た容器内にビームを導入する実験を 53 年 ${ }^{14)}$ と 54 年 ${ }^{15)}$ に行 った．53年の実験では $30 \mathrm{kV} ， 7 \mathrm{~A}$ ，引きだし持続時間 $100 \mathrm{~ms}$ のイオン源を用い，引きだし持続時間 $100 \mathrm{~ms}$ ，デ ューティサイクル $10 \%$ の水素イオンビームをクライオポ ンプに導入した. この時の実験の構成を図 5 に示す. この実験ではビーム引きだし持続時間が短く，排気性能 の悪化は認められなかった. また，クライオパネルとシ エブロン一の熱入力を液体へリウムと液体窒素の蒸発量

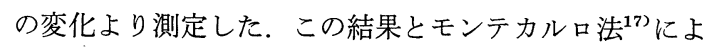
る計算結果との比較から，パネルとシェブロンへの熱入 力の増加は, ビームダンパーからの後方散乱粒子と熱輻 射とによるものとして説明することができた．54年の実 


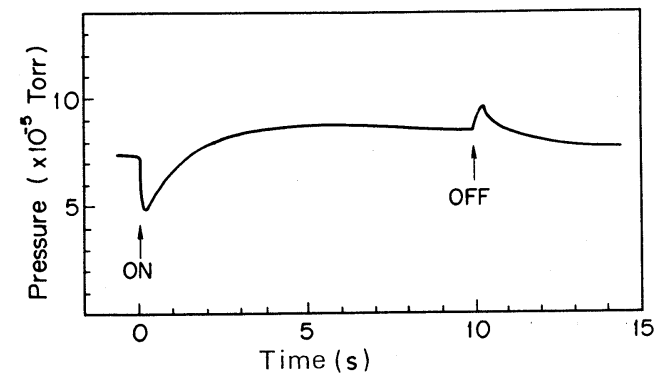

図 6 ビーム入射中のポンプ内圧力変化

験では, この年開発した設計仕様 $75 \mathrm{kV} ， 6 \mathrm{~A}$, 引きだ 乙持続時間 $10 \mathrm{~s}$ のイオン源 ${ }^{18)}$ を用い，引き出し持続時間 $10 \mathrm{~s}$ のビームをクライオポンプ内に導入した. 図 6 にこ の時のクライオポンプ内の圧力変化を示す.

ビーム入射時と消滅時の圧力低下と上昇は, 真空容器 等の表面での水素吸收と放出によるものと思われ，クラ イオポンプを動作させていないときにも見られるもので ある ${ }^{18)}$. ビーム入射約 3 秒後に一定の圧力を示すが，入 射前より数\%高くなっている. ビーム入射前も入射中も
イオン源への水素ガス流量すなわちクライオポンプへの ガス流量は一定なので，ビーム入射中は排気速度が減少 したことになる.この排気速度の低下は，ビーム入射中 のパルス熱負荷によりパネル溶接部の温度が上昇し, 水 素ガスが放出されることによるものと考えられる．JT60用中性粒子入射装置のクライオポンプでは, クライオ ポンプが直接受熱面を見込まないように水冷バッフルを 設けるなどの工夫をして，パルス熱負荷をここでの実験 よりは小さくすることにより，ビーム入射中のパネル溶 接部からの水素ガス放出を抑えることにしている.

\section{JT-60 用中性粒子入射装置原型ユニット}

\section{のクライオポンプ}

原型ユニットは JT-60用中性粒子入射装置 (実機) の プロトタイプの意味をもつので，大部分を実機と同一に 作る，最も大きい違いはJT-60本体とプラズマのかわり にトーラス模擬容器を置くことであり, この中にビーム ターゲットと水素を排気するためのクライオポンプを置 く. 図 7 にトーラス模擬容器を含んだ原型ユニットの図

\section{トーラス模㢸容器}

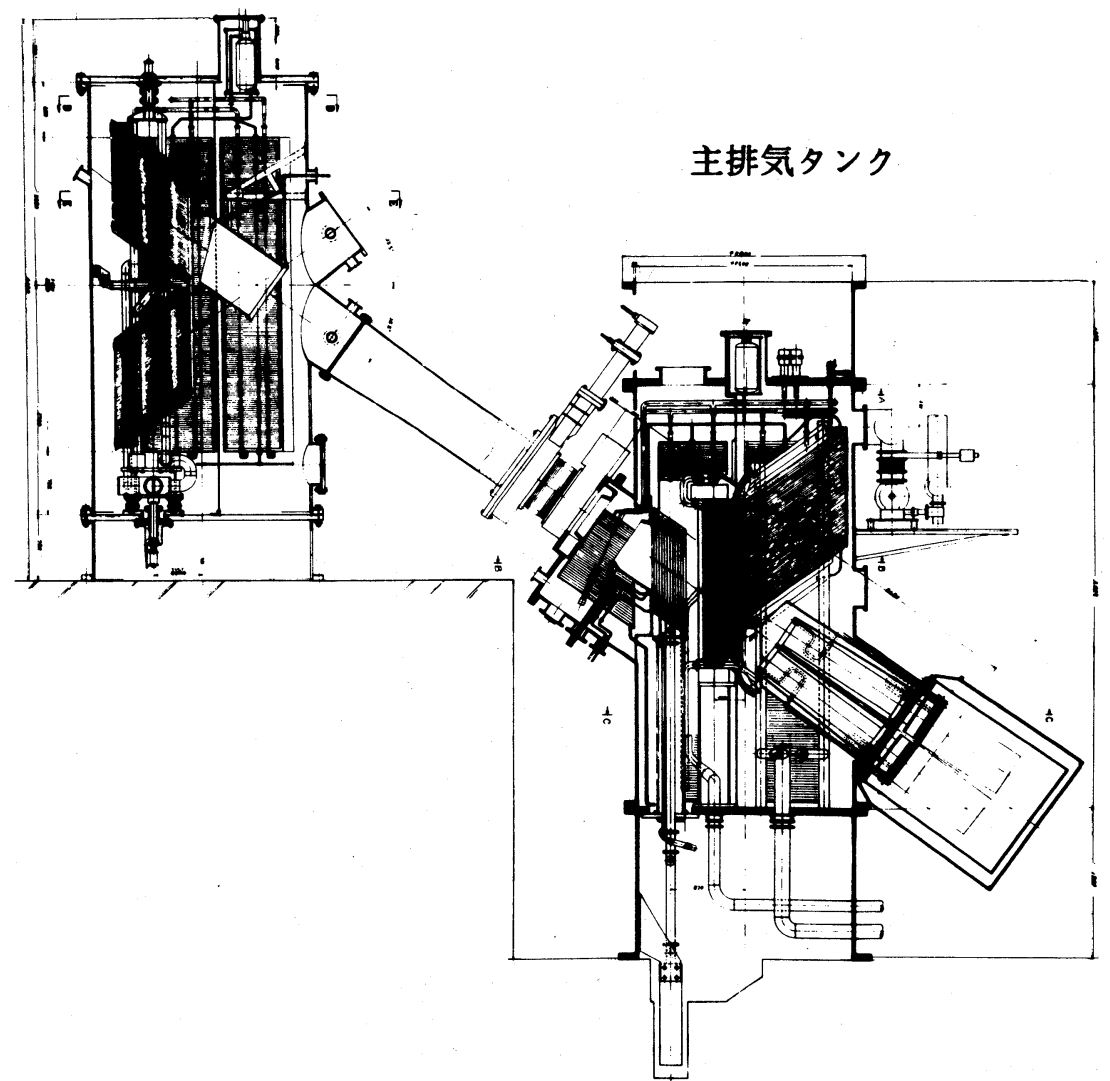

図 7 JT-60 用中性 粒子入射装置原型 ユニット 


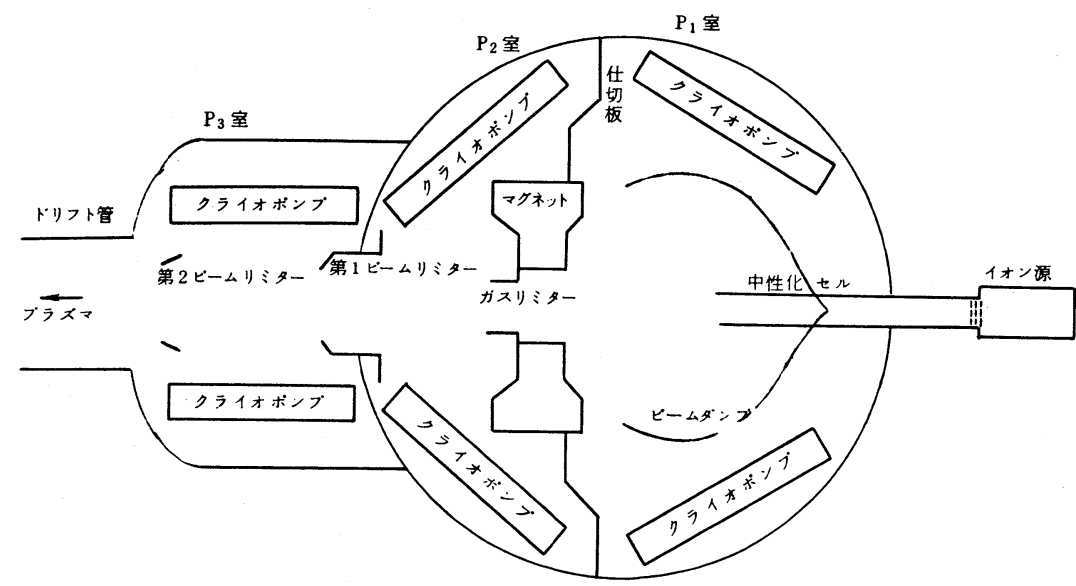

図 8 主排気タンク内の クライオポンプの配置

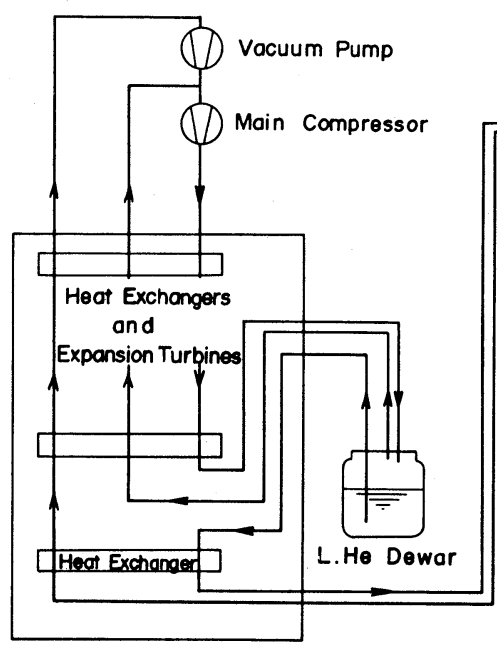

Cold Box

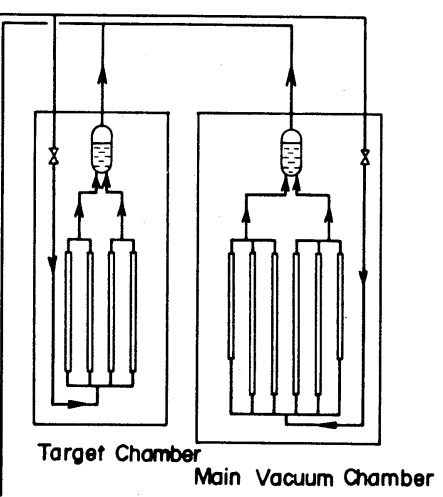

図 9 液体ヘリウム循環系の概略図
を示す. 図 8 に主排気タンク内のクライオポンプの配置 の平面図を示す.

主排気タンク内は $\mathrm{P}_{1}, \mathrm{P}_{2}, \mathrm{P}_{3}$ 室の三つに仕切られ,それ ぞれ一対のクライオポンプで差動排気する。それぞれの 室での排気速度は $6 \times 10^{5} \mathrm{l} / \mathrm{s}, 6 \times 10^{5} \mathrm{l} / \mathrm{s}, 7 \times 10^{4} \mathrm{l} / \mathrm{s}$ で，作動中の圧力は $5 \times 10^{-5}$ Torr, $1.5 \times 10^{-5}$ Torr, 8 $\times 10^{-6}$ Torr である。

クライオパネルの候補としてステンレス鋼をキルティ ング構造にしたものと, アルミニウムのフィン付管の二 つを考えた. 中性粒子入射装置はトーラスプラズマによ る変動磁場があり，これによる渦電流がクライオパネル 内を流れて発熱する，パネルに電気抵抗の小さいアルミ ニウムを用いると, 渦電流によるパルス熱負荷で排気不 能になる可能性があるので, キルティング構造のステン レス鋼をパネルに用いることにした ${ }^{19)}$. シェブロンは $120^{\circ}$ に曲げたアルミニウム板をすだれ状に並べ表面を黒 化処理する ${ }^{20)}$. パネルの冷却方式には液体ヘリウムのた
めこみ方式を選んだ. 強制循環方式を選ばなかったの は，ためこみ方式のほらがパルス熱負荷に対し抵抗があ り, 将来実機での14ユニットへの並列供給も容易と考え たためである、シェブロンやシールド板の液体窒素によ る冷却はポンプ圧送方式を選んだ.これはためこみ方式 では真空容器内に気液分離器等が必要となって, 内部配 管が複雑になるためである. 表 1 にヘリウム系への熱負 荷, 図 9 に液体ヘリウム循環系の概略図を示す.

冷凍機の能力は $3.7 \mathrm{~K}, 200 \mathrm{~W}$ とした. 推定熱負荷は表

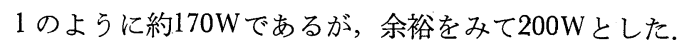
タンク内の推定圧力（最も低いところで $8 \times 10^{-6}$ Torr) でも十分な排気速度をもつためには，パネルを $3.9 \mathrm{~K}$ 以 下にすればよい，一方，渦電流発熱等のパルス熱負荷に よるパネル表面温度上昇は約 $0.2 \mathrm{~K}$ と評価される ${ }^{19)}$ ので, 冷凍機の冷却温度を $3.7 \mathrm{~K}$ とした. 液体ヘリウム系全体 は閉サイクルで，クライオパネルは冷凍機に直結してお り，パネル上部の気液分離器で発生した大気圧以下のへ 
表 1 原型ユニット液体ヘリウム系への熱負荷の評価

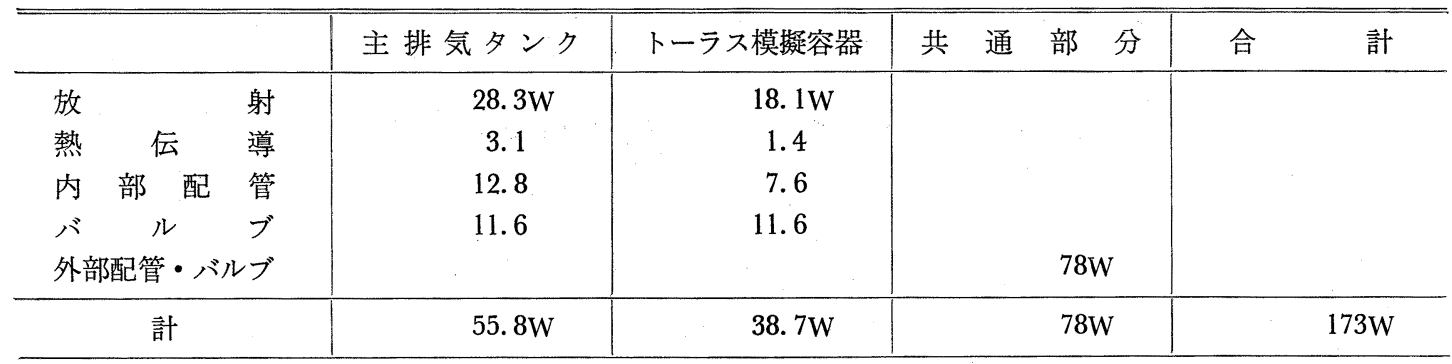

リウム蒸気は，コールドボックスにもどし寒冷を回収す る. $1,000 l$ の液体ヘリウムデュワーはパネルの予冷 時 間を短くするのに用いる，パネル温度の制御は回収ガス ラインの圧力を一定にすることにより行い，液体へリウ ム供給の制御は気液分離器の液面を一定にすることによ り行う。主排気タンクとトーラス模擬容器への液体へリ ウムと液体窒素の供給は並列供給で行うが，これは実機 の14ユニットへの並列供給を模擬することになる.

JT-60 中性粒子入射装置のクライオポンプのための液 体へリウムと液体窒素の循環系は, 昭和55年に詳細設計 を行い，これと原型ユニットの実験結果を見て57年には 製作に入る予定である.

\section{[文献}

1) 松田慎三郎，下村安夫：日本原子力学会誌 22, No. 10 (1980).

2）松田慎三郎，荒川義博，堀池 寛，伊藤孝雄， 河合視己人, 近藤梅夫, 森田洋昭, 小原祥裕, 大 賀徳道，奥村義和，桜庭順二，柴田猛順，白形弘 文, 田中 茂 : 日本原子力研究所報告 JAERI-M 7655 (1978).

3) Y. Shimomura et al.: 日本原子力研究所報告 JAERI-M 9065 (1980).

4) M. M. Menon et al.: J. Appl. Phys., 50 (1979) 2484.

5) J. Kim. et al: J. Appl. Phys., 51 (1980) 1984.

6) D. W. Doll, J. M. Kamperschroer and P. V. Arend: Proc. 8th Symp. Engineering Problems of Fusion Research, San Francisco, (1979) p. 2155.

7) 飯吉厚夫, 大引得弘 : 私信

8) L. E. Valby: Proc. 7th Symp. Engineering
Problems of Fusion Research, Knoxville, (1977) p. 1040.

9) L. C. Pittenger et al.: Proc. 8th Symp. Engineering Problems of Fusion Research, San Francisco, (1979) p. 831.

10) J.R. Coupland et al.: Proc. 9th. Symp. Fusion Tech., Garmish-Partenkirchen, (1976), p. 903.

11) N. N. Semasko et al.: "Injector for large thermonuclear apparatus” 熱核融合炉の技術問題に ついての全ソ会議，レニングラード (1977)（口 シア語).

12）柴田猛順, 松田慎三郎, 白形弘文, 斉藤正樹, 水野正保, 小宮宗治 : 日本原子力研究所 報 告, JAERI-M 7792 (1978).

13）柴田猛順, 奥村義和, 桜庭順二 : 日本原子力研 究所報告, JAERI-M 7869 (1978).

14）桜庭順二, 大賀徳道, 柴田猛順：日本原子力研 究所報告, JAERI-M 8013 (1978).

15）柴田猛順, 水谷泰彦, 奥村義和, 桜庭順二, 柴沼 清: 日本原子力研究所報告, JAERI-M 投稿中.

16) C. Benventi, R. \& Calder and G. Passardi: J. Vac. Sci. Technol., 13 (1976) 1172.

17）桜庭順二, 柴田猛順：日本原子力研究所報告, JAERI-M 7611 (1978).

18) Y. Okumura, S. Matsuda, Y. Mizutani, Y. Ohara and T. Ohga: Rev. Sci. Instrum. 51 (1980) $72,8$.

19) 柴田猛順, 堀池 寛, 栗山正明, 松田慎三郎, 桜庭順二, 白形弘文 : 日本原子力研究所 報 告, JAERI-M 8935 (1980).

20) S. Isobe, T. Ueda, T. Shibata, H. Shirakata, S. Matsuda: Proc. 8th. Symp. on Engineering Problems of Fusion Research, San Francisco, (1979) p. 533. 